\title{
Giant vallecular cyst: an impending threat for airway collapse
}

\author{
Surya Ravichandran 주, Puducherry Ravichandran Subhashini 다 , Kalaiarasi Raja, \\ Arun Alexander
}

ENT, Jawaharlal Institute of Postgraduate Medical Education and Research, Puducherry, India

\section{Correspondence to}

Dr Puducherry Ravichandran Subhashini;

prsubhashini90@gmail.com

Accepted 6 June 2021

\section{DESCRIPTION}

The vallecular cyst is formed due to an obstruction in the collecting duct of a submucosal gland, thereby causing the accumulation of mucus within it. It is also known as a ductal cyst, mucus-retention cyst. DeSanto et $a l^{1}$ identified that these vallecular cysts are due to distended ducts and not distended glands as histopathologically, the cells of these cysts are typically squamous or respiratory epithelium and not of acinar cells. As it is a rare entity, the exact incidence is not known. Vallecular cysts can occur in any part of the oropharynx due to the presence of numerous mucus glands within the lining epithelium. In children, vallecular cysts are

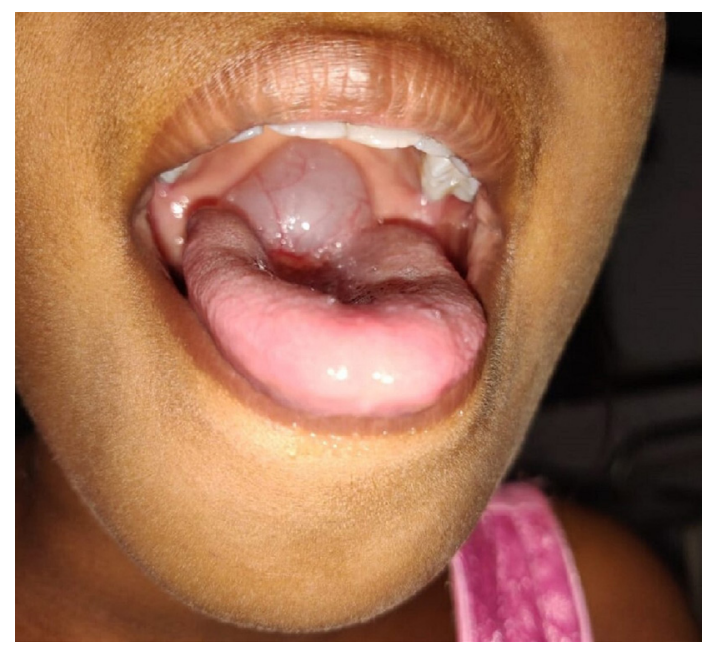

Figure 1 Picture showing vallecular cyst on mouth opening.

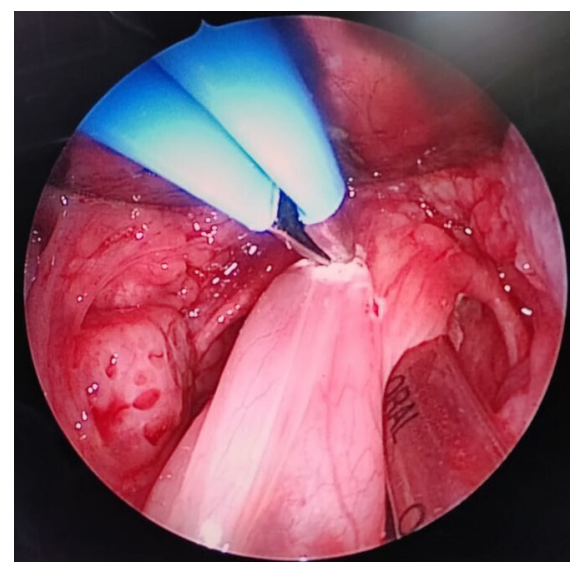

Figure 2 Cauterisation of the attachment of the vallecular cyst after aspiration.

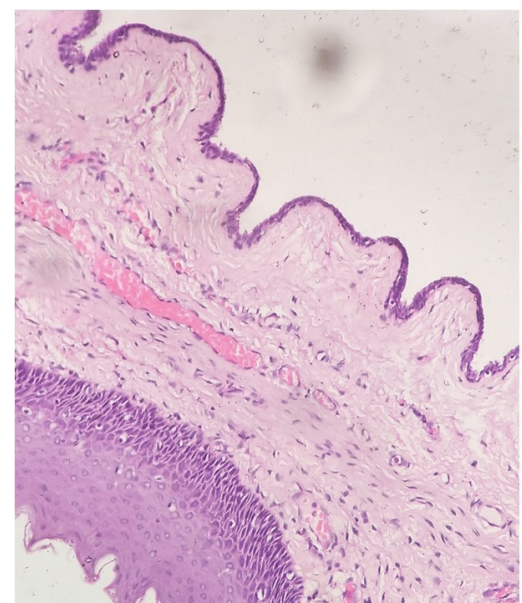

Figure 3 Histopathological examination of the excised cyst showing outer lining of squamous epithelium.

most commonly found in the base of the tongue and vallecula. ${ }^{2}$ Vallecular cysts are largely aymptomatic; however, they can cause upper airway obstruction, making the child present with stridor and respiratory distress if it grows large. Surgical excision is the mainstay treatment. Multiple intubation attempts are best avoided as there is a high risk of rupture of the cyst and aspiration of the cyst contents. ${ }^{3}$ The transoral median glossotomy approach and transhyoid approach, which carry an increased risk of prolonged intubation, need for postoperative tracheotomy and rarely pharyngocutaneous fistula, have been primarily replaced by transoral excision procedures. $^{4}$

Aspiration of the vallecular cyst to shrink its size followed by intubation has been recorded in the literature. ${ }^{56}$ However, marsupialisation via coblation has been the treatment of choice for vallecular cyst. $^{7}$

A 7-year-old girl was admitted as a case of difficulty in swallowing. On examination, a smooth cystic lesion was noted in the base of the tongue occupying the oropharyngeal isthmus (figure 1). Clinically, a diagnosis of the vallecular cyst was made. Difficulty in endotracheal intubation was anticipated. As the child was apprehensive for awake fibreoptic intubation, the child was preoxygenated for $3 \mathrm{~min}$ and induced with sevoflurane starting from 1\%. Mask ventilation was initiated, and the child was on spontaneous breathing. When the child was under, at 3\%, the cyst obstructed the glottis completely. The child started desaturating to $<90 \%$ momentarily. Direct laryngoscopy with 
Macintosh blade showed it would be impossible to intubate with the cyst unruptured. The cyst was held with a Magill's forceps, lifted and aspirated. Around $2 \mathrm{~mL}$ of clear fluid was aspirated from the cyst, following which it collapsed on itself. Once the cyst was aspirated, the airway opened, and with the child

\section{Patient's perspective}

Our child reported difficulty in swallowing for a few months. We noticed the significant swelling in her mouth and were worried that it could be a grave condition. The doctors explained the benign nature of the disease; however, they warned us about the potential risk of causing breathing difficulty. After the surgery, our daughter recovered completely, and we are happy that our terrifying experience came to an end. We thank the doctors and the treating staff for their efforts and commitment to our daughter's treatment.

\section{Learning points}

- Vallecular cysts are usually asymptomatic but can be present with respiratory distress and stridor.

- If found incidentally and hampering endotracheal intubation, transoral aspiration can be done to gain airway access.

- The tongue should have been pulled out, the nasopharyngeal airway should have been inserted and connected to the endotracheal tube adapter, and sevoflurane continued with $100 \%$ oxygen as the child was continuing spontaneous breathing, which could have prevented the airway collapse.

- Aspiration of the cyst must be followed by definitive management such as excision of the cyst as aspiration alone leads to a higher chance of re-accumulation of the fluid. breathing spontaneously, saturation improved to $100 \%$ quickly. Endotracheal intubation was successful. Under general anaesthesia, the vallecular cyst was examined using a $0^{\circ}$ endoscope, and it was found to be arising from the lingual surface of the epiglottis. The base of the vallecular cyst attached to the lingual surface of the epiglottis was cauterised (figure 2), the sac was removed and sent for histopathological examination. The child was extubated uneventfully. Histopathological examination of the excised material confirmed our diagnosis of the vallecular cyst (figure 3).

Contributors SR and SPR: data collection, manuscript preparation and review of literature. KR and AA: review and editing of the final manuscript.

Funding The authors have not declared a specific grant for this research from any funding agency in the public, commercial or not-for-profit sectors.

Competing interests None declared.

Patient consent for publication Parental/guardian consent obtained.

Provenance and peer review Not commissioned; externally peer reviewed.

\section{ORCID iDs}

Surya Ravichandran http://orcid.org/0000-0002-4579-9835

Puducherry Ravichandran Subhashini http://orcid.org/0000-0002-8904-7168

Arun Alexander http://orcid.org/0000-0003-1026-4678

\section{REFERENCES}

1 DeSanto LW, Devine KD, Weiland LH. Cysts of the larynx--classification. Laryngoscope 1970;80:145-76.

2 Wong KS, Li HY, Huang TS. Vallecular cyst synchronous with laryngomalacia: presentation of two cases. Otolaryngol Head Neck Surg 1995;113:621-4.

3 Walshe $\mathrm{CM}$, Jonas N, Rohan D. Vallecular cyst causing a difficult intubation. $\mathrm{Br}$ J Anaesth 2009;102:565.

4 Chen EY, Lim J, Boss EF, et al. Transoral approach for direct and complete excision of vallecular cysts in children. Int J Pediatr Otorhinolaryngol 2011;75:1147-51.

5 Vijayanand H, Mudhol RS, Patil PH, et al. Innovative surgical management of large vallecular cysts. Indian J Otolaryngol Head Neck Surg 2009;61:147-9.

6 Bestas A, Demirel I, Kaygusuz I. Airway management in an adult patient with a large vallecular cyst. J Med Cases 2014;3:160-2.

$7 \mathrm{Ma}$ E, Gopagondanahalli KR, Yong JS-ern, et al. Congenital vallecular cyst causing severe inspiratory stridor in a newborn. J Pediatr Surg Case Rep 2020;59:101460.

Copyright 2021 BMJ Publishing Group. All rights reserved. For permission to reuse any of this content visit https://www.bmj.com/company/products-services/rights-and-licensing/permissions/

BMJ Case Report Fellows may re-use this article for personal use and teaching without any further permission.

Become a Fellow of BMJ Case Reports today and you can:

- Submit as many cases as you like

- Enjoy fast sympathetic peer review and rapid publication of accepted articles

- Access all the published articles

- Re-use any of the published material for personal use and teaching without further permission

Customer Service

If you have any further queries about your subscription, please contact our customer services team on +44 (0) 2071111105 or via email at support@bmj.com.

Visit casereports.bmj.com for more articles like this and to become a Fellow 